\title{
Moving consensus and managing expectations: media and REDD+ in Indonesia
}

\author{
Tim Cronin ${ }^{1,2}$ - Levania Santoso ${ }^{2}$. \\ Monica Di Gregorio ${ }^{2,3}$ - Maria Brockhaus ${ }^{2}$. \\ Sofi Mardiah ${ }^{2,4} \cdot$ Efrian Muharrom ${ }^{2}$
}

Received: 15 February 2015 / Accepted: 19 November 2015 /Published online: 2 December 2015

(C) The Author(s) 2015. This article is published with open access at Springerlink.com

\begin{abstract}
This paper investigates policy actors' positions on reducing emissions from deforestation and forest degradation (REDD+) expressed in Indonesian media, and shows how these policy debates have evolved between 2007 and 2012. Results indicate media debates have moved beyond early, buoyant consensus on REDD+ as a win-win solution for economic growth and environmental conservation, to clearly acknowledge the need for institutional and governance reform. Several shifts in the frequency and nature of REDD+ discourse around 2010 - including from an international to a national level focus and an increase in the level of optimism - suggests the 2010 Letter of Intent between Indonesia and Norway has the potential to be a significant driver of change. Results also indicate that translating political will into measurable performance at a local or jurisdictional level is likely to require a broader appreciation of the complex interests, expectations and implications associated with the necessary reforms, and stronger engagement with key actor groups whose vested interests go beyond REDD+ itself. We observe an apparent desire on the part of Indonesian national authorities to have their cake and eat it too; that is, to keep their forest and clear it too.
\end{abstract}

\section{Introduction}

Carbon emissions from land use change - primarily tropical deforestation and forest degradation-account for as much as 15-20\% of all global carbon emissions (Intergovernmental Panel on Climate Change (IPCC) 2007). Reducing emissions from deforestation and forest degradation (REDD+) has thus become a key area of debate in climate change policy

Tim Cronin

timpcronin@hotmail.com

1 WWF-Australia, Sydney, Australia

2 The Center for International Forestry Research, Bogor, West Java, Indonesia

3 University of Leeds, Sustainability Research Institute, Leeds, West Yorkshire, UK

4 UN Office on Drugs and Crime, Jakarta, Indonesia 
processes. Mitigating climate change by compensating forest-rich developing countries in return for preserving their forests has been presented as a more cost-effective solution to mitigating climate change than many other greenhouse gas abatement options (Stern 2006). REDD + was officially recognised in the UN Framework Convention on Climate Change (UNFCCC) Copenhagen Accord in December 2009, and was further endorsed in a more formal package of decisions at the Cancun climate summit in December 2010. ${ }^{1}$ Yet many questions remain about policy design and implementation, especially at the national and subnational level.

Indonesia is the world's third largest emitter of carbon, and more than $75 \%$ of the country's emissions come from deforestation. In this way, Indonesia's REDD+ policies are not just nationally but globally significant. Indonesia has been a major supporter of REDD+, having enacted numerous regulations and established various institutions to ease the way for REDD+ implementation.

While policy-makers often rely on scientific expertise to inform policy processes - which they portray as rational, objective, and evidence-based - in reality public policy and environmental governance are fundamentally political processes, influenced by a multitude of interests, strategies and beliefs, as well as discursive practices that are used to frame policy discourses (Hajer 1995; Jasanoff 2009). A variety of policy actors influence REDD+ policy discourse and one way they do this is through the media (Di Gregorio et al. 2015). Investigating how REDD+ has been portrayed in the media in the last decade in Indonesia, can therefore help us to understand how the REDD+ policy agenda and public perceptions of REDD+ have evolved over time.

This paper investigates how the media represent policy debates around REDD + to the Indonesian public, specifically in relation to the following key questions: 1) To what extent has REDD + emerged as a domestic policy issue and not just a global one? 2) Whose voices on REDD + are represented in Indonesian media and how prominent are they? 3) To what extent do these voices advocate for substantive policy reform to address the drivers of deforestation in Indonesia?

After a background section on REDD+ policy processes in Indonesia and the role of the media in representing these processes, the paper describes the methods we applied to identify and analyse media representations of REDD+ policy debates. The results highlight a shift from international to national focus, the diversity of perspectives of different policy actors, and the prevalence of an optimistic win-win storyline on REDD+ during its first decade of emergence in Indonesia.

\section{Indonesia's REDD+ policy process and the role of the media}

Policy processes, events and actors all contribute to shape how REDD+ is understood (Di Gregorio et al. 2015. They also contribute to affect the salience of REDD+ in the media

\footnotetext{
${ }^{1}$ The evolution of the REDD+ debate has seen a gradual expansion of scope: from RED, or 'avoided deforestation' as it was referred to at COP 11 in Montreal, Canada; to REDD, incorporating avoided forest degradation, which was endorsed at COP 13 in Bali, Indonesia; to REDD+, including forest conservation, sustainable management of forests and reforestation/afforestation, which was first proposed in early 2009. Some have even proposed REDD++, which includes carbon sequestration from agricultural activities. The model endorsed in the Copenhagen Accord is accepted to be REDD+.
} 
(Entman 1993, p.53). which in turn affects public opinion, and thus policy processes, events and actors.

\subsection{National REDD+ policy processes in Indonesia}

Since the 2007 UNFCCC Conference of the Parties (COP) held in Bali, Indonesia has engaged in REDD+. Indonesia is unique in the global climate change arena because its greenhouse gas emissions profile is heavily dominated by emissions from forest and peat lands, both areas in which more efficient land use can increase economic returns as well as reduce greenhouse gas emissions. Consequently, Indonesia has actively participated in multilateral initiatives driving REDD+ at the global level (these include the World Bank's Forest Carbon Partnership Facility and the United Nation's Collaborative Programme on REDD+ [UN-REDD]). At the national and subnational level, Indonesia has enacted numerous regulations and established various institutions to ease the way for REDD+ implementation. The situation remains highly dynamic - including since the 2014 change in government - but at the time of writing some of the key REDD+ institutions and organizations include the Indonesian Forest Climate Alliance (IFCA), the National Council on Climate Change (DNPI) and the REDD+ Agency (Fig. 1).

Indonesia was the first large developing country to announce, during the G20 meeting in Pittsburgh in September 2009, a significant voluntary emission reduction target; in this case $26 \%$, or up to $41 \%$ with international assistance. In May 2010 Indonesia signed a Letter of Intent (LoI) with the Norwegian Government, through which the Norwegians pledged US\$1 billion to help Indonesia address deforestation, forest degradation, and peat land conversion. The bilateral partnership involves a range of initiatives, including micro-financing, institutional capacity building and other policies and measures. It has been a significant driver of landmark policy reforms including the Presidential moratorium on new forest concession licenses, issued in May 2011 - renewed twice since - and a Constitutional Court ruling in May 2013, which recognizes customary forests as separate to state forests.

REDD+ has arrived just a decade into Indonesia's extensive decentralization process, and the underlying struggle for control of and access to forest resources remains largely unresolved

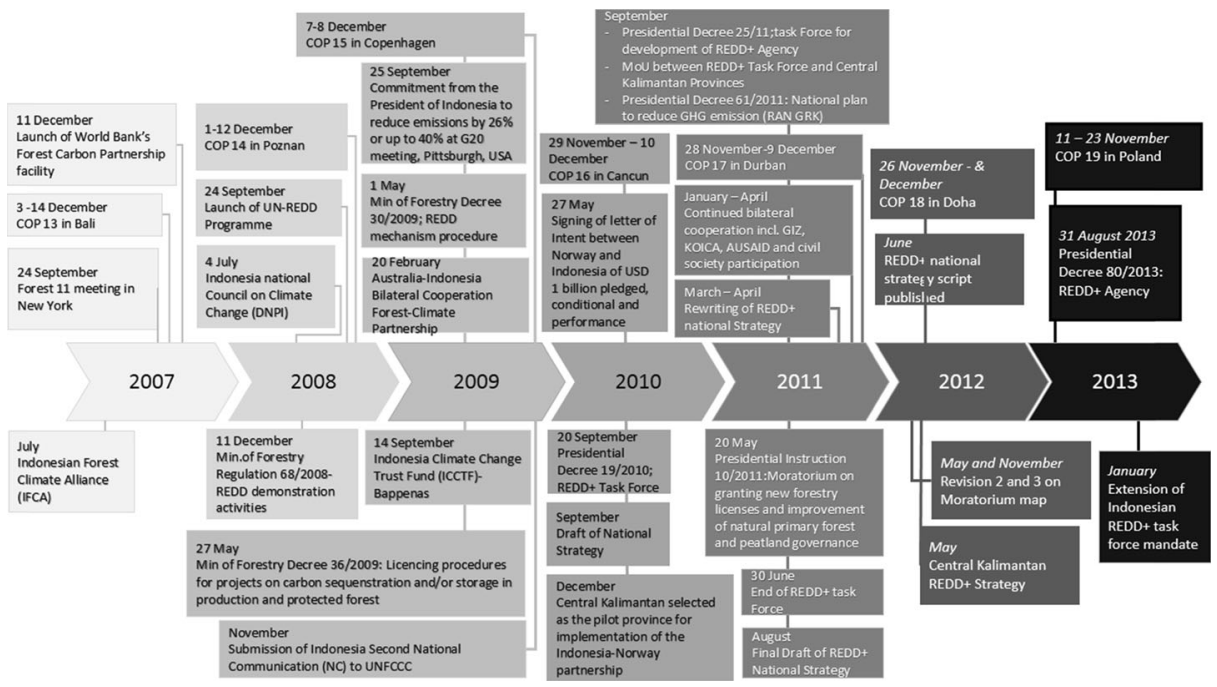

Fig. 1 "REDD+"-related policy events in Indonesia 
(Moeliono 2009). Rates of deforestation and degradation in Indonesia remain high (Margono et al. 2014). Nevertheless, some observers consider the 2010 LoI with Norway to represent a major turning point in Indonesia's approach to forest governance that could help deliver the enabling policy environment for REDD + to work (Murdiyarso et al. 2011). In a 2012 interview (Lang 2012). CIFOR's Director General Frances Seymour described the LoI as prompting:

"A tectonic shift in the dialogue about forests, who participates in it, realignment of domestic constituencies among themselves and vis-à-vis international constituencies in a way that I haven't seen in 25 years."

\subsection{REDD+ and the media}

Such major shifts can be identified in many different ways, including through media coverage. The media, however, does not just portray policy events and discourses, it also contributes to shape them. According to Boykoff (2008, p. 550). mass media are an "influential and heterogeneous set of non-nation state actors" that function as both windows onto, as well as participants in, informal and formal discourses. On the one hand, media reports reflect existing social perceptions of an issue and the power structures involved. On the other, media reports affect social perceptions of an issue and the power structures involved. They do this through framing, which means:

"To select some aspects of a perceived reality and make them more salient in a communicating text, in such a way as to promote a particular problem definition, causal interpretation, moral evaluation, and/or treatment recommendation for the item described." (Entman 1993, p. 52).

In other words, media frames define problems, diagnose causes and promote specific solutions. The power of a frame is its ability to bring certain aspects of reality into sharper focus, while relegating other aspects to the background.

Not surprisingly, policy actors interact with the media in various ways to try to influence news and media coverage, and therefore how the public perceive a particular problem or potential solution (Kiousis et al. 2006; Boykoff and Smith 2010). Evidence also shows that more powerful actors dominate media coverage and, consequently, the media often tend to support the status quo (Boykoff 2008; Carvalho 2007). Media coverage is, therefore, the result of mutual influence among policy events, policymakers, and the media themselves. By examining the way policy processes are framed in the media - for example REDD + in Indonesia - and how various actors represent their interests to strengthen political coalitions and affect public opinion, we can identify some of the main challenges in the policy arena on a given issue.

As long as the media has been reporting on climate change there have been studies about how this coverage has reflected and affected climate change policy. One common thread, at least in the West, is that coverage of climate change tends to uphold the political and economic status quo. For example, tabloid newspapers in the UK adopt tones of fear, misery, and doom in order to foster "inertial acceptance of status quo inequities rather than motivation to address associated issues of climate change, socio-economic disparity, and differential vulnerability" (Boykoff 2008, p. 563). Media representations of climate change are often strongly entangled with ideological standpoints, with some outlets maintaining an ideological preference for 
"a non-regulatory government and reinforcement of the social and economic status quo" (Carvalho 2007, p. 231).

There have been fewer studies into media coverage of climate change in developing countries (Shanahan 2009; Painter 2010). and those studies that have been carried out have tended to focus on English-language newspapers, even though these tend to have much narrower reach than their vernacular equivalents (Painter 2010). Painter's study on media coverage of COP15 contends that media coverage of climate change in many of the world's poorer countries is "woefully inadequate and insufficient to match either the scale of the problem or the degree of vulnerability" (Painter 2010, p. 20). He also cites "too cosy a relationship between the media and national political leaders, which can lead to an unquestioning attitude of the powers-that-be or an overwillingness to blame the West for global warming” (p. 20).

This paper is part of a series of studies by CIFOR investigating REDD+ media discourse in Indonesia, Brazil, Cameroon, Nepal, Papua New Guinea, Peru and Tanzania (Cronin and Santoso 2010; May et al. 2011; Kengoum 2011; Pham 2011, Khatri et al. 2012; Babon et al. 2012; Alvarez et al. 2012; Kweka 2013, Di Gregorio et al. 2014). Overall, results of these studies tend to support the findings on climate change coverage in the West, with national level policy discourse rarely challenging the direct nor indirect drivers of deforestation and degradation. This paper is an extension and elaboration of the Indonesia case.

It is worth noting the limitations of media analysis in providing an accurate and comprehensive reflection of policy debates and public perceptions, especially in developing countries. Although focusing on local language coverage is likely to improve the breadth and accuracy, illiteracy and geographical diffusion is still likely to impede the reach of this coverage (especially in a vast archipelago like Indonesia), while the level of press freedom will affect the diversity and nature of voices being heard. Freedom House, a U.S.-based think tank, classifies Indonesia's media as only "partly free" in its annual Freedom of the Press Report.

Given the historical development of REDD+ in Indonesia, coupled with evidence from previous media discourse analyses, we might expect REDD+ media coverage in Indonesia to reflect: 1) the evolution of REDD+ policy in Indonesia, including towards a stronger focus on implementation after 2010;2) the emergence of an increasing diversity of stakeholders related to Indonesia's forest sector; 3) a reluctance to directly challenge the major drivers of deforestation.

\section{Methods}

The media analysis undertaken here focuses on articles that discuss REDD + and which have appeared between December 2005 (when REDD+ first appeared on the international agenda) and December 2012, in select Indonesian media. Three national newspapers were selectedKompas, Media Indonesia, and Republika - to represent a broad geographical, social, and political spectrum. Daily circulation of Kompas is approximately 500,000, making it the most widely read newspaper in Indonesia. It spans the religious and ethnic spectrum. Daily circulation of Media Indonesia is approximately 300,000 - the third highest in Indonesiaand its target audience is middle to upper class. Daily circulation of Republika is approximately 100,000, concentrated largely in Java and Sumatra. Republika's target audience is the Muslim community and the majority of its readers are women. 
The population of news articles for the media analysis was compiled through an electronic Boolean query using the keywords "REDD", "reducing/reduced emissions from deforestation and forest degradation", and "avoided deforestation". ${ }^{2}$ All three newspapers are published in Indonesian language.

Between 2007 and 2012 a total of 649 articles mentioning REDD+ appeared across all three newspapers. Within the population of 649 articles that mention "REDD+", 45 were considered just passing references, which left 604 articles for in-depth coding and analysis. Coding involved data collection at four levels. The first three levels used a standardized codebook. Level 1 coding captures descriptive variables only, including the date, author, and length of the article. Level 2 coding compiles specific characteristics of the media articles, including the main topics and scale at which it is positioned. Level 3 coding identifies policy actors that are cited in the media articles and their opinion statements - or stances (Kockleman 2004) - on REDD+. The study identified 829 individual stances across the 604 articles.

Level 4 used inductive open coding to pool individual stances of these policy actors. We did so by grouping direct quotes - or other attribution of opinion to a specific named policy actor in the media - under broader stance categories where they shared a common (or meta) world view on REDD+. This aggregation produced a total of 10 'stance categories', which are in fact frames, enabling us to associate actor groups with specific REDD + -related discourses in Indonesia.

Much of the analysis in this paper refers to these stances and associated frames. While acknowledging the important role of media as participants in informal and formal policy processes, in this paper we use media accounts primarily as a window into policy processes, to reflect how policy actors represent their opinions in the media. While the focus is therefore on non-media policy actors, we do identify media as policy actors in the case of editorial or opinion pieces. These account for $4 \%$ of all actors that put forward positions on REDD+ (see Fig. 4).

\section{Results and discussion}

\subsection{From global events to national policies}

The first mention of REDD+, or avoided deforestation, in Indonesian media occurred in 2007, two years after the concept first emerged on the global climate change agenda. This coincided with Indonesia's hosting of COP13 in Bali in December 2007. Between 2007 and 2012 a total of 649 articles mentioning REDD+ appeared across all three newspapers. Figure 2 illustrates fairly constant growth in coverage following a drop in 2008 (38 articles), with a visible spike from 2010 (86) to 2011 (203). This period included a number of significant national level policy processes, including a bilateral partnership agreement with Norway, a Presidential Moratorium on Forest Clearance (PRI 2011) and establishment of a REDD+ Agency.

This data also reflects another trend. That is, in the early years of REDD+ Indonesian media coverage was very much tied to international events; specifically the UNFCCC Conference of the Parties, held annually in December. Between 2007 and 2009, $68 \%$ of all media coverage

2 "REDD", "pengurangan emisi dari deforestasi dan degradasi hutan" and "pencegahan deforestasi" in Indonesian. 


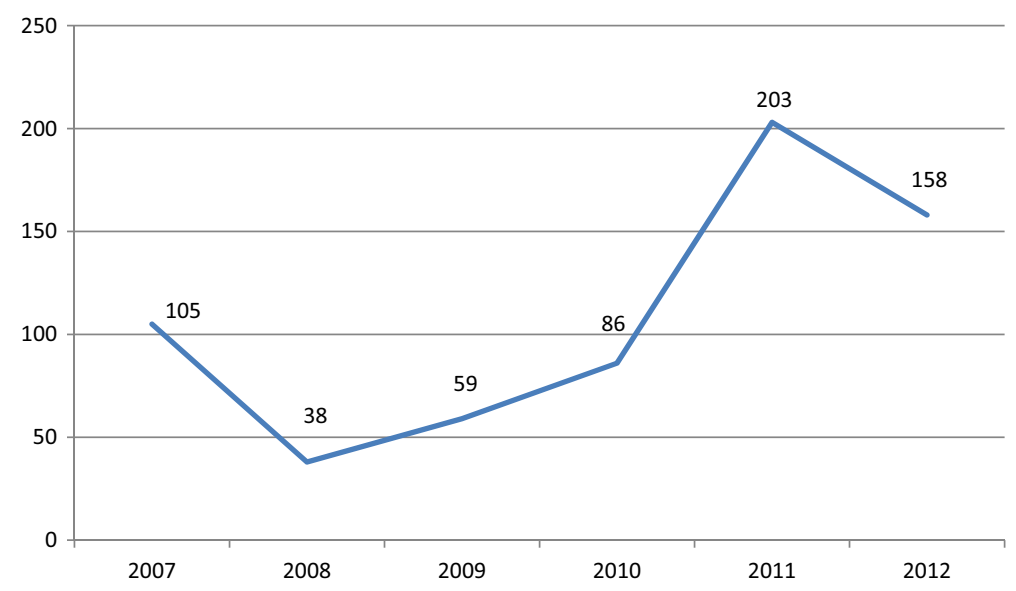

Fig. 2 Frequency of "REDD+" articles in selected Indonesian national newspapers

appeared in the December quarter. This percentage drops to $37 \%$ between 2010 and 2012, reflecting a more varied media focus.(Fig. 3).

This trend is further illustrated when we see the political 'level' at which the media articles are positioned (Fig. 4). Between 2007 and 2009, $53 \%$ of all coverage is focused on international issues, with the bulk of the remainder at the national level. Between 2010 and 2012 , this percentage of international coverage more than halves, dropping to just $24 \%$. Conversely, $58 \%$ percentage of media coverage now shifts to the national level, with a further $14 \%$ located at the sub-national level. Even local level issues, which had been largely absent from national coverage until 2009, started to emerge. While this is likely to be quite a natural evolution as an issue like REDD+ matures, it is possible that the shift was at least in part triggered, or accelerated, by the bilateral agreement with Norway in 2010.

\subsection{A variety of voices, some louder than others}

Within the media reports, an actor is cited on 829 occasions making a specific ideological, personal, or political stance on REDD+. Indonesian state actors are the most frequently cited

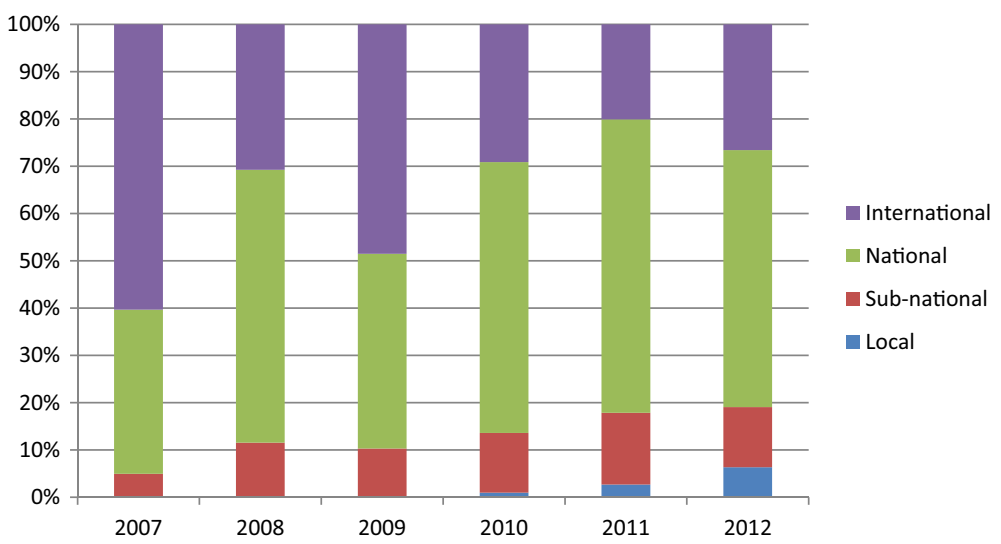

Fig. 3 Reporting level of media coverage on "REDD+" (\% of total articles) 


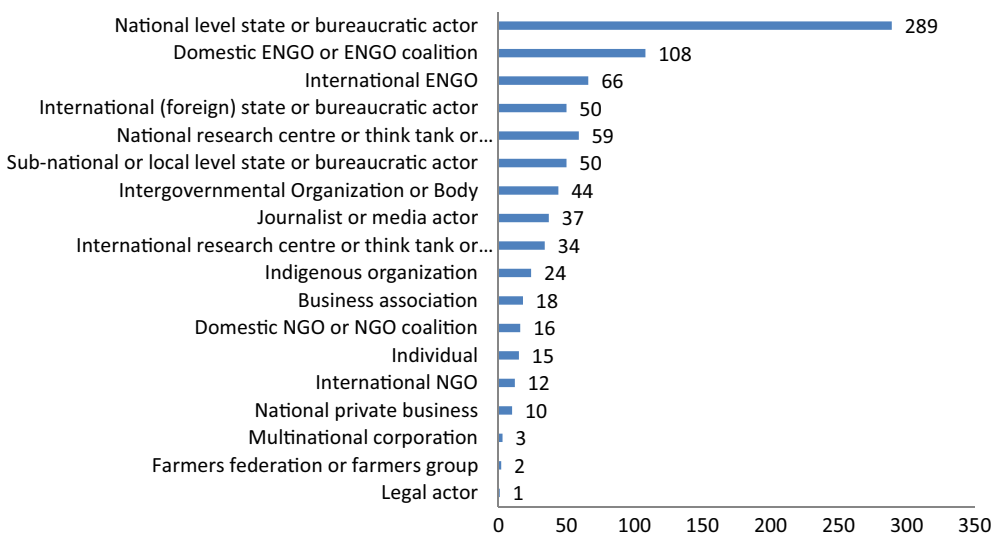

Fig. 4 Frequency of positions on "REDD+" put forward in the media by each actor group

actor group, most of them at the national level (35\%, or 289 stances, see Fig. 4). Indonesian government bodies include representatives from the Indonesian Ministries of Forestry (112 stances) and Environment (29), the National Climate Change Council (46) and REDD+ Task Force (24). Indonesian sub-national and local-level government representatives make up a further $6 \%$ of stances $(50)$, as do state actors from other nations, bringing the total proportion of state actors to just under half (47\%).

The Indonesian Ministries of Forestry and Environment, as well as the National Climate Change Council, are clearly crucial for REDD+ design and implementation. However, there is a conspicuous lack of input into REDD+ discourse from other Ministries, especially considering that, for REDD+ to be successful, "any rules must be capable of synchronising all policies relating to REDD+ application, which will be connected to spatial planning, finance and regional autonomy" (Regional Legislative Assembly member Sarwono Kusumaatmadja, quoted in Kompas 2008). The Ministries of Agriculture (1), Public Works (1) and Economic Affairs (4) are featured sparingly, as is the National Development Planning Agency (7).

Non-Government Organisations (NGOs) make up $24 \%$ of actors. The coding distinguishes between international and domestic NGOs, and between environmental NGOs (ENGOs) and others. The most commonly cited NGO group over the six year period is domestic ENGOs (108 stances), which make up $53 \%$ of all NGOs or $13 \%$ of all actors (see Fig. 4). These include the Indonesian Forum on Environment (Walhi), Indonesian Center for Environmental Law (ICEL) and Greenomics. Again this reflects a shift in perspective from the early years of REDD+ reporting, with international ENGOs - such as WWF, Greenpeace, and Flora \& Fauna International (FFI) - the dominant NGO group between 2007 and 2009 (11\% of all stances compared to $5 \%$ for domestic ENGOs).

National and international research centers, think tanks, and academic institutions account for a further $11 \%$ of actors (93 stances), while intergovernmental organizations (including the UNFCCC and World Bank) make up $5 \%$ (44 stances). Private sector actors - including national and multi-national corporations and business associations - are featured on just 31 occasions (4\%) in total, and were virtually absent until 2010. Journalists or media actors put forward their own positions on REDD+, for example in opinion pieces or editorials, on 37 occasions (4\%).

The dominance of national state actors within media-based discourse on REDD+ is consistent with the literature on media analysis, which finds official sources such as 
government representatives tend to get advantaged access to the news media and as a result become primary definers of key issues (Carvalho 2007; Anderson 2009). Nevertheless there is a broad representation of other stakeholders on REDD+ being heard in Indonesian media, which reflects the broad range of interests in the future of Indonesia's forests, particularly at a time when control of and access to forest resources remains largely unresolved (Moeliono 2009).

At the same time, the scant representation of many of these groups, compared to the prevalence of government representatives, raises questions about power, equality, and the potential for state actors to inform and influence public opinion and policy process on REDD+. The absence of the private sector in media coverage on REDD+ is surprising, particularly given their prominent role in managing and exploiting Indonesian forest resources.

\subsection{How broad is REDD+ optimism?}

Overall, between 2007 and 2012, $61 \%$ of stances on REDD+ offered an optimistic assessment of its likely impact on Indonesia. Another $19 \%$ were pessimistic, $9 \%$ neutral, and $11 \%$ offered no judgment. Broken down over time this optimism, while still dominant, declines somewhat from 2007 (64\%) to 2010 (51\%). This decline coincides with the 2009 COP15 meeting in Copenhagen - which failed to make any meaningful progress towards a global agreement on climate change - while a subsequent return in confidence coincides with the significant national level policy events we have seen throughout late 2010 and 2011, revolving around implementation of the bilateral partnership agreement with Norway and including the Presidential Moratorium on Forest Clearance.

Future assessments of REDD+, charted against particular actor type reflect a substantial diversity in opinions. For example, national-level Indonesian state actors (80\%) were highly optimistic about REDD+. On the other hand, indigenous groups (38 \%), farmers (50\%), and domestic NGOs (41\%) were much less optimistic. This striking difference between the perspectives of state actors and certain factions of civil society highlights the difficulty of building consensus in designing and implementing REDD+. Moreover, the fact that the largely-pessimistic indigenous groups, farmers, and domestic NGOs make up just $8 \%$ of actors cited in the media articles on REDD+, compared to $35 \%$ for national state actors, indicates that their concerns may be heavily marginalized in media discourse on REDD + , and potentially in REDD+ policy processes.

\subsection{From win-wins to trade-offs}

Ten categories of stances on REDD+ expressed by actors were identified through open coding (Table 1), which characterize the scope of discourse on REDD+ within the three selected newspapers. These stance categories, or frames, cover a broad range of issues and topics, ranging from concerns over indigenous rights and access (RIGHTS) and constraints to Indonesia's economic growth (GROWTH), to opinions on financing mechanisms (MARKET) and sources of funding (INTERNATIONAL FINANCE).

The significance granted to these debates within Indonesian media can be seen in the frequency of the various stance categories (see Table 1), while the level of consensus around particular views can, to some extent, be seen in the coding of 'agree' versus 'disagree'. More pertinent, however, in reflecting the range and divergence of interests in on REDD + , is the variety of stance categories themselves (see Table 1), which reflect the extent to which policy 
Table 1 Stance categories on REDD+ (17 stances categorized as 'other' are not included)

Stance Category

Agree Disagree

GOVERNANCE: REDD+ will require major governance and institutional reform

8

SOLUTION: REDD+ (or at least forests) should be part of the global solution to climate change

INTERNATIONAL FINANCE: REDD+ should be financed by developed countries

SCOPE: REDD+ should incorporate avoided degradation, conservation and reforestation, not just avoided deforestation

RIGHTS: REDD+ risks reducing access to forest resources and harming traditional forest $\quad \begin{array}{lll}68 & 8\end{array}$ users

GROWTH: REDD+ should not compromise Indonesia's economic growth, including that $\quad 48 \quad 24$ generated through agricultural expansion

CENTRALISED: REDD+ programs should be formulated and managed at the national level $46 \quad 46 \quad 8$

CAPACITY BUILDING: REDD+ will require major technical capacity building $\quad 45 \quad 4$

CO-BENEFITS: REDD+ should provide co-benefits apart from combating climate change $\quad \begin{array}{lll}4 & 2\end{array}$

MARKET: REDD+ should be financed by a carbon offsetting market mechanism $\quad 21 \quad 10$

TOTAL $709 \quad 103$

discourse encompasses a range of political and socio-economic perspectives. Therefore, we predominantly consider the stances that agree, or align with, a particular category, and explore the ways in which these relate to other categories, rather than analyse the interaction between 'agree' and 'disagree'.

The two most frequent stance categories, which together accounted for more than $40 \%$ of the total 829 stances, were "REDD+ will require major institutional and governance reform" (GOVERNANCE; 160 occasions, or $19 \%$ ) and "REDD+ should be part of the global solution to climate change" (SOLUTION; 136 or $16 \%$ ).

The discourse around REDD+ as a solution to climate change echoes the broad optimism illustrated in Section 4.3, but also represents win-win rhetoric consistent with what Saunders et al. describe as a "light touch version of sustainable development" (2010), which leaves existing inequalities unchallenged and fails to address the complex shifts and trade-offs in policy, society and industry that will be required to make a scheme like REDD+ work.

On the other hand, stances related to the need for major institutional and governance reform point very much to the need for change, and start to acknowledge the systemic flaws in Indonesia's forestry sector that have contributed to the country's historically high levels of deforestation. Consider, for example, the following statement from the Indonesian Center for Environmental Law:

"There are classic problems in the governance structure: corruption, poor institutional and inter-sectoral coordination, and legal uncertainty. If these are not resolved, then any mechanism applied will fail" (12th December 2007; Kompas).

As we have seen in our analysis of other trends - including frequency, level and outlook there was something of a shift in REDD+ media discourse around 2010. Discourse around governance reform became particularly pronounced following Indonesia's Letter of Intent with Norway in early 2010. To illustrate, between 2007 and 2009, the GOVERNANCE frame was the fourth most frequent, accounting for 27 (12\%) of 220 stances put forward by policy actors 
in the media. Between 2010 and 2012, this proportion more than doubled, to 138 (28\%) of 495 stances.

Other stance categories that grew in prominence between 2007 and 09 and 2010-12 were those calling for REDD+ to incorporate a broad scope of land uses (SCOPE; from $6 \%$ to $12 \%$ of total stances for the period, and 7th to 3rd in frequency); and those calling for REDD+ not to jeopardise Indonesia's economic growth (GROWTH; $5 \%$ to $8 \%$ and 10th to 5 th). Both categories relate to complex debates around trade-offs and opportunity costs, illustrated in the level of polarization among stances linked to GROWTH; with a third of all stances coded as 'disagree' (compared to an average of just $13 \%$ across all stance categories).

Consider, for example, the following statement from the Indonesian Association of Forest Concessionaires, in relation to a proposed moratorium on new forest concessions: "Business sees the moratorium as a barrier for them ... (and) as a form of foreign dictatorship to Indonesia in forest management" (4th October 2010; Republika). Not only does this frame REDD + as a barrier to economic growth, it touches on additional issues of sovereignty and international relations, which we'll explore in more detail in the next section as we consider who is saying what.

\subsection{Keep the forest and clear it too?}

There is no escaping the fact that national-level state actors are the dominant voice in REDD+ reporting (Fig. 4), so it's important to understand these actors' most common positions if we are to understand the nature of REDD+ public discourse in Indonesia.

We have seen that the future assessment of REDD+ from national state actors in Indonesia is predominantly optimistic, but that there are notable gaps in which national Ministries are cited. We have also seen that the third most frequent stance category across all actor groups is "REDD+ should be financed by developed countries" (INTERNATIONAL FINANCE, Table 1), which was put forward on 75 occasions. On 34 of these 75 occasions, this stance was put forward by a national-level, Indonesian state actor.

This stance positions tropical forests as providing global environmental services and is generally based on the premise that developing countries like Indonesia will be forced to curtail their economic growth by locking up their forests as carbon sinks. They must, therefore, be compensated accordingly. Consider the following position articulated by Indonesia's Minister of Forestry, M.S. Kaban, in 2007:

For Kaban, as long as there is no commitment from developed countries to adopt REDD, global efforts to resolve climate change will remain unfair. "If there are no ties [emission reduction targets] for developed countries, developing countries will have no certainty, because the prop for developing countries is resources," he said (Media Indonesia 2007).

At the same time, other stance categories frequently put forward by national state actors in Indonesia are that "REDD+ should incorporate avoided degradation, conservation and reforestation, not just avoided deforestation" (SCOPE, 31 occasions) and "REDD+ should not compromise Indonesia's economic growth, including that generated through agricultural expansion" (GROWTH, 24 occasions). Both positions are linked to ensuring REDD+ incorporates multiple land use options, including sustainable forest management and reforestation. This could potentially mean rewards for reduced impact logging and industrial-scale plantation forestry, which would enable Indonesia to capitalize on international funding for forest 
preservation, while also enjoying economic growth opportunities through forest conversion. As Kaban stated before COP13: "REDD must not be counterproductive to utilising industrial plantation forests as revenue sources" (Trahutama and Suhartono 2007).

This apparent desire for Indonesia to keep its forest and clear it too does not necessarily contravene the principles of REDD+, given many issues relating to scope and forest definition are yet to be entirely resolved (Angelsen and McNeil 2012). It does, however, illustrate something of a disconnection between political discourse on REDD+, and the practical realities of REDD+. This disconnection is highlighted by the conspicuous absence of a corporate voice within media reporting, despite the fact that private sector actors driving deforestation and forest degradation in Indonesia will need to be engaged in REDD+ policy making if REDD+ is to work (Indrarto et al. 2012).

In any case, debates around land use and economic development within REDD+ are clearly related to questions of land tenure security faced by smallholders and the rights of local and indigenous communities (Larson 2010; Myers Madeira et al. 2010; Sunderlin et al. 2013). However, on only 8 occasions did a national state actor address the concern that "REDD + risks reducing access to forest resources and harming traditional forest users" (RIGHTS). Beyond state actors, however, 'rights' was one of the most common frames, put forward (76 stances in total), most frequently by Indigenous organizations (18 times) and ENGOs (15 times by international organizations and 11 times by domestic).

What is clear is that for REDD+ to work in Indonesia will require major change. What is not clear is what this change will look like. The need for change is reflected most clearly in the high frequency of discourse around the "need for major governance and institutional reform" (GOVERNANCE). While it is encouraging to see this need increasingly recognized by those in positions of power, it also reinforces the difficulty that Indonesia will face in reconciling these reforms with an apparent expectation of business as usual; particularly given that many of those needed to drive and implement the reforms (e.g. ministries other than Forestry and private sector actors) are scarcely engaged in public debates on REDD+.

\section{Conclusion}

This paper has investigated how policy actors' opinions on REDD+ are represented in Indonesian media, with a view to identifying potential challenges in the policy process. Overall, there was has been a sustained increase in reporting on REDD+ from 2008 to 2011 (following an early spike in media attention as Bali hosted the UNFCCC COP13 in December 2007), before a drop in 2012. We have seen that, over time, focus has gradually shifted from milestone international meetings to domestic policy events and that state actors remain the dominant voice in REDD+ reporting.

The national REDD+ policy arena in Indonesia features many competing interests, both within and beyond government. Although stakeholders are predominantly optimistic about REDD+, policy discourse reveals the difficulty of addressing such diverse interests. Media debates have moved beyond early, buoyant consensus on REDD + as a win-win solution for economic growth and environmental conservation, to clearly acknowledge the need for institutional and governance reform.

The timing of these shifts in discourse suggest that the 2010 LoI between Indonesia and Norway may have been something of a catalyst, including in moving political will from the global to the national level. The 2011 Presidential moratorium on clearing primary forest and peatland areas - in part driven by the Norwegian agreement -reflects this political commitment. Nevertheless, translating political will into measurable performance at a local or 
jurisdictional level, is likely to require the engagement and support of key actor groups including the private sector - whose vested interests go beyond REDD+ itself.

Open Access This article is distributed under the terms of the Creative Commons Attribution 4.0 International License (http://creativecommons.org/licenses/by/4.0/), which permits unrestricted use, distribution, and reproduction in any medium, provided you give appropriate credit to the original author(s) and the source, provide a link to the Creative Commons license, and indicate if changes were made.

\section{References}

Alvarez JP, Montero DF, Barrantes EB, Takahashi TP, Menton M (2012) Políticas REDD+ y los medios de comunicación: caso de estudio en el perú. In: Documento de trabajo 101. Indonesia, CIFOR, Bogor

Anderson A (2009) Media, politics and climate change: towards a new research agenda. Sociol Compass 3(2): 166-182

Angelsen A, Mcneil D (2012) The evolution of REDD+. In: Angelsen A, Brockhaus M, Sunderlin WD, Verchot LV (eds) Analysing REDD+: challenges and choices. CIFOR, Bogor

Babon A, McIntyre D, Sofe R (2012) REDD+ politics in the media: a case study from Papua New Guinea. In: Working paper 97. Indonesia, CIFOR, Bogor

Boykoff MT (2008) The cultural politics of climate change discourse in UK tabloids. Political Geography 27:549-569

Boykoff MT, Smith J (2010) Media presentations of climate change. In: Lever-Tracy C (ed) Routledge handbook on climate change and society. Routledge, London

Carvalho A (2007) Ideological cultures and media discourses on scientific knowledge: re-reading news on climate change. Public Underst Sci 16(2):223-243

Cronin T, Santoso L (2010) REDD+ politics in the media: a case study from Indonesia. In: Working paper 49. Indonesia, CIFOR, Bogor

Di Gregorio M, Brockhaus M, Cronin T, Muharrom E, Mardiah S, Santoso L (2014) Talking the talk of change: REDD+ discourse in the national media. Sustainability Research Institute, School of Earth \& Environment, University of Leeds, Leeds

Di Gregorio M, Brockhaus M, Cronin T, Muharrom E, Mardiah S, Santoso L (2015) Deadlock or transformational Change? Exploring public discourse on REDD+ across seven countries. Global Environmental Politics. doi:10.1162/GLEP_a_00322

Entman R (1993) Framing: toward clarification of a fractured paradigm. J Commun 43(4):51-58

Hajer MA (1995) The politics of environmental discourse: ecological modernization and the policy. Clarendon Press, Oxford, UK

Indrarto GB, Murharjanti P, Khatarina J, Pulungan I, Ivalerina F, Rahman J, Prana MN, Resosudarmo IA, Muharrom E (2012) The context of REDD+ in Indonesia. In: CIFOR working paper 92. Center for International Forestry Research, Bogor, Indonesia

Intergovernmental Panel on Climate Change (IPCC) (2007) Summary for policymakers. Cambridge University Press, Cambridge, UK

Jasanoff S (2009) Border crossings: social sciences and public policy. In: Guimaraes Pereira A, Silvio Functowicz S (eds) Science for policy. Oxford University Press, Oxford, UK

Kengoum, D.F. 2011. REDD+ politics in the media. A case study from Cameroon. Working Paper 51. CIFOR, Bogor, Indonesia

Khatri DB, Bhushal RP, Paudel NS, Gurung N (2012) REDD+ politics in the media: a case study from Nepal. In: Working paper 96. Indonesia, CIFOR, Bogor

Kiousis S, Mitrook M, Wu X, Seltzer T (2006) First- and second-level agenda-building and agenda-setting effects: exploring the linkages among candidate news releases, media coverage, and public opinion during the 2002 Florida gubernatorial election. J Public Relat Res 18(3):265-285. doi:10.1207/s1532754xjprr1803_4

Kockleman P (2004) Stance and subjectivity. Journal of Linguistic Anthropology 14(2):27-150

Kweka D (2013) REDD+ politics in the media: a case study from Tanzania. In: Working paper 119. CIFOR, Bogor, Indonesia

Lang, C. 2012. "Interview with Frances Seymour, CIFOR: "The Letter of Intent prompted a tectonic shift in the dialogue about forests". REDD-Monitor - http://www.redd-monitor.org/2012/04/13/interview-with-francesseymour-cifor-the-letter-of-intent-prompted-a-tectonic-shift-in-the-dialogue-about-forests/

Larson A (2010) Forest tenure reform in the age of climate. Lessons for REDD+. Global Environmental Change, Change. doi:10.1016/j.gloenvcha.2010.11.008 
Margono BA, Potapov VP, Turubanova S, Stolle F, Hansen MC (2014) Primary forest cover loss in Indonesia over 2000-2012. Nat Clim Chang 4:730-735

May, P. H., Calixto, B., Gebara, M. F. 2011. REDD+ politics in the media: A case study from Brazil. Working Paper 55. CIFOR, Bogor, Indonesia.Media Indonesia (2007) Semua negara sepakat kerja jangka panjang (REDD programme fought for in Bali). Media Indonesia, October 26

Moeliono M (2009) Decentralization, recentralization and devolution in Indonesia. In: Angelsen A (ed) Realising REDD+: national strategy and policy options. CIFOR, Bogor, Indonesia, p. 178

Murdiyarso D, Dewi S, Lawrence D, Seymour F (2011) Indonesia's forest moratorium: a stepping stone to better forest governance? Working paper 76. CIFOR, Bogor, Indonesia

Myers Madeira E, Sills E, Brockhaus M, Verchot L, Kanninen M (2010) What is a REDD+ pilot? A preliminary typology based on early actions in Indonesia. In: Infobrief 26. Indonesia, CIFOR, Bogor

Painter J (2010) Summoned by science: reporting on climate change at Copenhagen and beyond. Reuters institute for the study of journalism. University of Oxford, UK

Pham, T.T. 2011 REDD+ politics in the media: a case study from Vietnam. Working Paper 53. CIFOR, Bogor, Indonesia

Shanahan M (2009) Time to adapt? Media coverage of climate change in non-industrialised countries. In: Boyce T, Lewis J (eds) Global crises and the media Vol 5. Peter Lang, Oxford, UK

Stern N (2006) Review on the economics of climate change. UK Government Economic Service, London

Sunderlin, W. D., Larson, A.M., Duchelle, A. E., Resosudarmo, I. A. P., Huynh Thu Ba, Awono, A., Dokken, T., 2013. How are REDD+ proponents addressing tenure problems? Evidence from Brazil, Cameroon, Tanzania, Indonesia, and Vietnam. World Dev 55: page 37-52

Trahutama, N., Suhartono. 2007. Indonesia usulkan REDD—pencegahan deforestasi dikhawatirkan kontraproduktif (Indonesia proposes REDD + - deforestation prevention feared Counterproductive). Kompas November 6 